\title{
RESISTENSI Klebsiella sp. TERHADAP MEROPENEM DI RSUD PROF. DR. MARGONO SOEKARJO PURWOKERTO
}

\author{
Afifah Afifah ${ }^{1}$, Tunggul Adi Purwongroho ${ }^{2}$, I Dewa Sang Aju Putu Peramiarti ${ }^{1}$ \\ ${ }^{1}$ Fakultas Kedokteran, Universitas Jenderal Soedirman, Jalan dr. Gumbreg 01, Mersi, Purwokerto Timur 53112 \\ 2 Fakultas Ilmu-Ilmu Kesehatan, Universitas Jenderal Soedirman, Jalan dr. Suparno, Karangwangkal, Purwokerto 53122
}

\section{A B S T R A C T}

Resistant Gram-negative bacteria, particularly Klebsiella sp., has become a serious problem in hospitals as one of the leading causes of nosocomial infections spread through urine catheterization. Infections of Klebsiella sp. producing extended-spectrum beta-lactamase (ESBL) can lead to significant economic and clinical negative outcome. This study was aimed to determine the sensitivity of ESBL Klebsiella sp. against meropenem as a cause of nosocomial infections in Prof. Dr. Margono Soekarjo hospital. This research obtained urine samples from the urinary catheter of patients hospitalized for at least two days in the surgical ward and intensive care unit. ESBL examination conducted by the initial screen test, meanwhile, sensitivity test to meropenem carried out by disk diffusion test. Among the 40 patients examined in this study 7.5\% isolates were Klebsiella sp.-positive. This research identified five percent of the total patients as ESBL positive with the level of sensitivity against meropenem was revealed as resistant.

KEY WoRDS: Klebsiella sp., extended spectrum beta-lactamase (ESBL), meropenem, sensitivity

Dikirim: 24-03-2017 | Diterima: 08-05-2017

\section{PENDAHULUAN}

Klebsiella sp. merupakan patogen utama di rumah sakit terkait dengan meningkatnya insidensi bakteri penghasil extended spectrum $\beta$-lactamase (ESBL) (Superti et al., 2009), dan dapat menginfeksi pasien yang menjalani rawat inap dalam waktu lama (Ludden et al., 2015). Bakteri penghasil ESBL berperan penting pada tingginya kejadian infeksi nosokomial di rumah sakit. Infeksi ini merupakan salah satu dari enam penyebab utama terjadinya komplikasi serta kematian di Amerika dan Eropa (Ahmadi et al., 2013; Peleg \& Hooper, 2010). Sebesar 70-80\% penyebab infeksi pada pasien berasal dari penggunaan kateter selama perawatan di rumah sakit (Zarb et al., 2012).

Resistensi Klebsiella sp. telah menjadi masalah serius di rumah sakit sebagai akibat dari penyebaran infeksi nosokomial melalui kateterisasi urin (Aly et al., 2016). Penggunaan kateter urin yang tidak steril dapat meningkatkan risiko bakteri uria sebesar 5$10 \%$ per hari. Hal ini berbahaya karena dapat meningkatkan risiko terjadinya infeksi saluran kemih, pyelonephritis dan sepsis sehingga akan meningkatkan morbiditas serta mortalitas (Widodo, 2010; Peleg \& Hooper, 2010; Purnomo, 2008). Meningkatnya mortalitas berkaitan dengan terapi antibiotik yang tidak tepat terhadap bakteri penghasil ESBL (Tuon et al., 2011). Carbapenem merupakan antibiotik yang sangat efektif untuk infeksi bakteri Klebsiella sp., sehingga banyak digunakan secara luas. Salah satu antibiotik berspektrum luas yang termasuk dalam golongan carbapenem adalah meropenem. Resistensi Klebsiella sp. terhadap carbapenem disebabkan adanya carbapenemase, metallo- $\beta$-laktamase, dan hilangnya porin.

Penelitian Afifah \& Utami (2011) menunjukkan bahwa bakteri penghasil ESBL sebagai penyebab infeksi nosokomial di RSUD Prof. Dr. Margono Soekarjo adalah Klebsiella sp. (30\%), Proteus sp.
(10\%) dan Escherichia coli (10\%). Namun, penelitian mengenai resistensi Klebsiella sp. penghasil ESBL sebagai penyebab infeksi nosokomial di RSUD Prof. Dr. Margono Soekarjo belum pernah dilakukan. Penelitian ini bertujuan untuk mengetahui resistensi Klebsiella sp. penghasil ESBL terhadap meropenem sebagai penyebab infeksi nosokomial di RSUD. Prof. Dr. Margono Soekarjo, Purwokerto.

\section{MET ODE}

Penelitian dilakukan secara observasional analitik dengan pendekatan cross sectional. Sampel berasal dari 40 pasien bangsal bedah dan ruang perawatan intensif RSUD Prof. Dr. Margono Soekarjo Purwokerto yang menggunakan kateter urin (Folley). Pengujian sampel dilakukan di Laboratorium Mikrobiologi Fakultas Kedokteran Universitas Jenderal Soedirman.

Klebsiella sp. diisolasi dari urin kateter pasien yang telah dirawat minimal dua hari di bangsal bedah dan ruang perawatan intensif RSUD Prof. Dr. Margono Soekarjo Purwokerto, kemudian ditumbuhkan pada medium McConkey agar. Isolat yang diperoleh kemudian diuji menggunakan Initial Screen Test dan Phenotypic Confirmatory Test dengan metode Disk Diffusion Test pada medium Mueller Hinton Agar. Bakteri penghasil ESBL akan membentuk zona hambat terhadap cefotaxime dan ceftazidime sesuai Clinical laboratory standar institute (CLSI) dan menunjukkan peningkatan zona hambat di sekitar disk, terdapat selisih diameter $\geq 5 \mathrm{~mm}$ (Cockeril et al., 2010).

Uji sensitivitas Klebsiella sp. terhadap meropenem dilakukan dengan menggunakan metode Disk Difusion Test pada medium Mueller Hinton Agar. Kertas cakram berdiameter $6 \mathrm{~mm}$ ditetesi meropenem dengan dosis $10 \mu \mathrm{g}$ kemudian diletakkan pada sebaran biakan Klebsiella sp. Biakan diinkubasi pada suhu $37^{\circ} \mathrm{C}$ selama $16-18$ jam dan zona hambat yang terbentuk diamati.

Tingkat sensitivitas Klebsiella sp. terhadap meropenem dapat dibedakan menjadi tiga kategori, yaitu; sensitif, intermediet, dan resisten (Cockeril et al., 2010). 


\section{HASIL DAN PEMBAHASAN}

Koloni bakteri Klebsiella sp. yang diisolasi dari urin kateter pasien berbentuk bulat, ukuran kecil sampai sedang, permukaan konveks, mukoid, halus dan pinggir rata (Gambar 1A). Sel bersifat Gram negatif dan berbentuk batang (Gambar 1B).

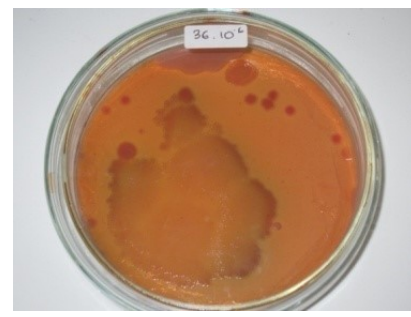

A

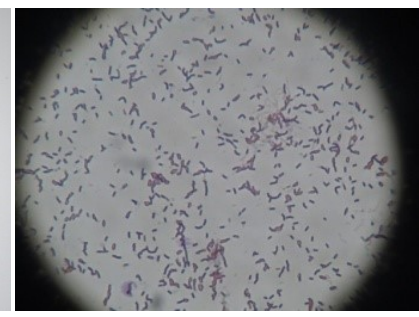

B
Gambar 1. (A) Morfologi koloni bakteri di media McConkey, (B) Gambaran mikroskopis pewarnaan Gram.

Hasil identifikasi biokimiawi melalui uji IMViC menunjukkan bahwa Klebsiella sp. yang diperoleh memiliki karakter Indol (-), Cimmons (-), Voges Proskauer (-), Methyl Red (+) dan uji fermentasi glukosa (+). Hasil isolasi dan identifikasi tersebut dikonfirmasi dengan karakter Klebsiella sp. menurut Holt et al. (2000).

Sebanyak 3 pasien menunjukkan hasil isolasi positif Klebsiella sp. (7,5\%) dari total 40 sampel pasien. Hasil tersebut berbeda dengan penelitian sebelumnya oleh Afifah \& Utami (2011) yang menunjukkan sebanyak 38\% sampel teridentifikasi Klebsiella sp. pada pasien ICU dan bangsal bedah. Penelitian lain oleh Mojtahedzah et al. (2008) dan Aly et al. (2016) didapatkan sebanyak $12 \%$ dan $50 \%$ pada pasien ICU terindentifikasi Klebsiella sp. Penyebab perbedaan hasil dengan penelitian sebelumnya antara lain dikarenakan adanya perbedaan demografi, periode waktu pengambilan sampel, faktor risiko yang mendasari, serta lamanya waktu penggunaan kateter pada pasien rawat inap (Aly et al., 2016; Mojtahendzah et al., 2008). Meskipun terdapat perbedaan persentase Klebsiella sp. (7,5\%-50\%) pada penelitian tersebut di atas, namun Klebsiella sp. menempati urutan pertama bakteri yang teridentifikasi dari sampel kateter urin pasien di ICU dan bangsal bedah dibandingkan bakteri lain. Hal tersebut menunjukkan bahwa Klebsiella sp. berperan penting pada terjadinya infeksi nosokomial akibat pemasangan kateter di rumah sakit. Hasil ini sesuai dengan penelitian Zolldann et al. (2003), Unal et al. (2005), Jeong et al. (2005), Kaoutar et al. (2004), Tuon et al. (2011) yang menunjukkan bahwa ICU merupakan tempat dengan infeksi nosokomial tertinggi dibandingkan bangsal rawat inap lainnya. Sedangkan penelitian Salmanzadeh et al. (2015) menunjukkan bahwa Klebsiella merupakan urutan keenam penyebab infeksi nosokomial di Rumah Sakit Razi pada tahun 2013. Perbedaan tersebut antara lain disebabkan oleh banyaknya jumlah pasien dalam penelitian, tempat penelitian dan faktor genetik.
Initial screen test terhadap Klebsiella sp. dari 3 sampel (7,5\%) menunjukkan 2 sampel (5\%) di antaranya adalah penghasil ESBL dan semua resisten terhadap meropenem. Metode initial screen test yang digunakan dalam penelitian ini memiliki kekurangan karena hasilnya kurang sensitif untuk mendeteksi adanya ESBL. Deteksi keberadaan ESBL seharusnya dilanjutkan dengan phenotypic confirmatory test sehingga diharapkan adanya ESBL dapat terkonfirmasi seperti rekomendasin Clinical Laboratory Standard Insititute (CLSI) tahun 2010. Persentase Klebsiella sp. tersebut berbeda dengan penelitian Tuon et al. (2011) yang menunjukkan sebanyak 58\% adalah Klebsiella sp. penghasil ESBL, akan tetapi sejalan dengan penelitian Tuon et al., (2011), Tsering et al. (2009), dan Ndugulile et al. (2005) yang menyebutkan bahwa Klebsiella sp. penghasil ESBL memiliki persentase lebih besar dibanding non ESBL. Spesies Klebsiella terbanyak yang dapat menghasilkan ESBL yaitu Klebsiella pneumonia dan Klebiella oxytoca (Tsering et al., 2009). ESBL merupakan enzim yang bekerja dengan menghambat antibiotik beta laktam. Berdasar pada aspek klinis dan epidemiologis, patogen penghasil ESBL berkaitan dengan penggunaan antibiotik spektrum luas seperti carbapenem. Hal tersebut mengakibatkan pasien menjalani rawat inap dan terapi antibiotik lebih lama. Resistensi bakteri yang berasal dari sampel pada pasien rawat inap di rumah sakit dapat disebabkan karena terapi antibiotik dan pemberian resep yang tidak tepat karena tanpa berdasar pada hasil kultur dan uji sensitivitas bakteri, serta adanya infeksi silang (Ferreira et al., 2011).

Uji sensitivitas Klebsiella sp. penghasil ESBL terhadap meropenem menunjukkan kedua sampel (5\%) berada pada kategori resisten. Meropenem termasuk dalam antibiotik carbapenem yang merupakan obat lini pertama infeksi bakteri penghasil ESBL. Namun demikian, sudah mulai ditemukan adanya resistensi bakteri terhadap meropenem. Seperti pada penelitian di RSUP Dr. M. Djamil Padang, yaitu sebanyak $12 \%$ Klebsiella sp. penyebab sepsis neonatorum di ICU dan perinatologi resisten terhadap meropenem (Putri et al., 2014). Selain itu, penelitian oleh Biswas et al. (2014) menunjukkan bahwa sebanyak 4 dari 200 sampel teridentifikasi ESBL dan semua resisten terhadap meropenem. Secara teori, meropenem stabil terhadap mayoritas enzim betalaktamase, termasuk AmpC betalaktamase, dan extended-spectrum beta-lactamases. Namun, resistensi terhadap meropenem dapat terjadi ketika bakteri mengubah struktur protein binding proteins, dan menghasilkan enzim metallo-beta-lactamases yang dapat secara cepat mendegradasi meropenem, atau ketika permeabilitas membran bakteri berubah sebagai akibat hilangnya spesifitas outer membrane porins (Zhanel et al., 2007). Telah dilaporkan bahwa protein membran luar Klebsiella sp. terdiri dari 3 jenis porin yaitu OmpK35, OmpK36, dan OmpK37 (Hernandez-Alles et al., 1999; Kaczmarek et al., 2006). 
Porin OmpK35 dan OmpK36 berperan penting pada penetrasi antibiotik ke dalam sel, sehingga hilangnya porin OmpK35 dan OmpK36 dapat menyebabkan resistensi bakteri terhadap carbapenem (Doumith et al., 2009; Goldfarb et al., 2009; Kontopoulou et al., 2010).

\section{KESIMPULAN DAN SARAN}

Telah ditemukan 3 sampel positif Klebsiella sp. dari 40 sampel, dengan 2 sampel di antaranya (5\%) teridentifikasi mengandung Klebsiella sp. yang memproduksi ESBL dalam sampel urin. Uji sensitivitas Klebsiella sp. penghasil ESBL terhadap meropenem menunjukkan kedua sampel (5\%) tersebut masuk dalam kategori resisten.

\section{DAFT AR REFERENSI}

Afifah A, Utami AD. 2011. Identification of extended spectrum betalactamase (ESBL) producing bacteria cause of nosocomial infection in RSUD Prof. Dr. Margono Soekarjo, Purwokerto. In: Totok A, Rifda N, Hardiansyah, Erna KW, Friska CA, Santi DA, Siti ZW, Ali M, Diah P, editors. Proceedings of the Seminar Nasional Pengembangan Sumber Daya Pedesaan dan Kearifan Lokal Berkelanjutan; 2011 Nov.; Purwokerto: LPPM Unsoed; p.502-508.

Ahmadi F, Abolghasemi S, Parhizgari N, Moradpour F. 2013. Effect of silver nanoparticles on common bacteria in hospital surfaces. Jundishapur J Microbiol. 6(3): 209 - 214.

Aly SA, Tawfeek RA, Mohamed IS. 2016. Bacterial catheterassociated urinary tract infection in the intensive care unit of Assiut University Hospital. Al Azhar Assiut Medical Journal. 14(2):52-58.

Biswas R, Rabbani R, Ahmed HS, Sarker MAS, Nahida Z, Rahman MM. 2014. Antibiotic sensitivity pattern of urinary tract infection at a tertiary care hospital. Bangladesh Crit Care J. 2 (1): 21-24.

Cockerill FR, Wikler MA, Bush M, Dudley MN, Eliopoulus GM, Hardy, DJ, et al. 2010. Performance standards for antimicrobial susceptibility testing: twentieth informational supplement. In CLSI Document M100-S20. Pennsylvania: Clinical Standarad and Laboratory Institute. 13(1): pp.40-160.

Doumith M, Ellington MJ, Livermore DM, Woodford N. 2009. Molecular mechanisms disrupting porin expression in ertapenem-resistant Klebsiella and Enterobacter spp. clinical isolates from the UK. J Antimicrob Chemother. 63(4):659-667.

Ferreira CM, Ferreira WA, Almeida NCOS, Naveca FG, Barbosa MGV. 2011. Extended-spectrum beta-lactamase-producing bacteria isolated from hematologic patients in Manaus, State of Amazonas, Brazil. Brazilian Journal of Microbiology. 42(3):1076-1084.

Goldfarb D, Harvey SB, Jessamine K, Jessamine P, Toye B, Desjardins M. 2009. Detection of plasmid-mediated KPC-producing Klebsiella pneumoniae in Ottawa, Canada: evidence of intrahospital transmission. J Clin Microbiol. 47(6):1920-1922.

Hernandez-Alles S, Alberti S, Alvarez D, Doménech-Sánchez A, Martinez-Martinez L, Gil J, Tomás JM, Benedí VJ. 1999. Porin expression in clinical isolates of Klebsiella pneumoniae. Microbiology. 145(3):673-679.

Holt SR, Murray EGD, Smith RN. 2000. Bergey's manual determinative of bacteriology. 9th ed. Baltimore: Waverly Press.

Jeong SH, Bae IK, Kwon SB, Lee K, Yong D, Woo GJ, Lee JH, Jung HI, Jang SJ, Sung KH, Lee SH. 2005. Investigation of a nosocomial outbreak of Acinetobacter baumannii producing PER-1 extended-spectrum beta-lactamase in an intensive care unit. J Hosp Infect.. 59(3):242-248.

Kaczmarek FM, Dib-Hajj F, Shang W, Gootz TD. 2006. High-level carbapenem resistance in a Klebsiella pneumoniae clinical isolate is due to the combination of bla(ACT-1) beta-lactamase production, porin $0 \mathrm{mpK} 35 / 36$ insertional inactivation, and down-regulation of the phosphate transport porin phoe. Antimicrob Agents Chemother. 50(10):3396-3406.

Kaoutar B, Joly C, L'Hériteau F, Barbut F, Robert J, Denis M, Espinasse F, Merrer J, Doit C, Costa Y, Daumal F, Blanchard HS, Eveillard M, Botherel AH, Brücker G, Astagneau P. 2004. Nosocomial infections and hospital mortality: a multicentre epidemiology study. J Hosp Infect. 58(4):268-275.

Kontopoulou K, Protonotariou E, Vasilakos K, Kriti M, Koteli A Antoniadou E, Sofianou D. 2010. Hospital outbreak caused by Klebsiella pneumoniae producing KPC-2 beta-lactamase resistant to colistin. J Hosp Infect. 76(1):70-73.

Ludden C, Cormican M, Vellinga A, Johnson JR, Austin B, Morris D. 2015. Colonisation with ESBL - producing and carbapenemase producing Enterobacteriaceae, vancomycin - resistant enterococci, and meticillin-resistant Staphylococcus aureus in a long-term care facility over one year. BMC Infect Dis. 15:168.

Mojtahedzadeh M, Panahi Y, Fazeli MR, Najafi A, Pazouki M, Navehsi BM, Bazzaz A, Naghizadeh MM, Beiraghdar F. 2008. Intensive care unit-acquired urinary tract infections in patients admitted with sepsis: etiology, risk factors, and pattern s of antimicrobial resistance. Int J Infect Dis. 12(3):312-318.

Ndugulile F, Jureen R, Harthug S, Urassa W, Langeland N. 2005. Extended spectrum beta-lactamases among Gram-negative bacteria of nosocomial origin from intensive care unit of a tertiary health facility in Tanzania. BMC Infect Dis. 5:86.

Peleg AY, Hooper DC. 2010. Hospital acquired infections due to Gram-negative bacteria. N Engl J Med. 362(19):1804 - 1813.

Purnomo BP. 2008. Kateterisasi dan Sirkumsisi. In Dasar-Dasar Urologi. Jakarta: Sagung Seto. p.237-244.

Putri SI, Djamal A, Rahmatini. 2014. Sensitivitas bakteri penyebab sepsis neonatorum terhadap meropenem di neonatal intensive care unit dan perinatologi RSUP DR M Djamil Padang Padang Tahun 2012. Jurnal Kesehatan Andalas. 3(3):475 - 479.

Salmanzadeh S, Yousefi F, Ahmadi F, Geravandi S, Moien M, Mohammadi MJ, Kohi AM, Alavi SMA, Esfarjani NM. 2015. Evaluation of nosocomial infections in a teaching hospital. Avicenna J Clin Microb Infect. 2(3):21 - 26.

Superti SV, Augusti G, Zavascki AP. 2009. Risk factors for and mortality of extended-spectrum- $\beta$-lactamase-producing Klebsiella pneumoniae and Escherichia coli nosocomial bloodstream infections. Rev Inst Med Trop Sao Paulo. 51(4):211-216.

Tsering DC, Das S, Adhiakari L, Pal R. Singh TS. 2009. Extended spectrum beta lactamase detection in Gram-negative bacilli of nosocomial origin. J Global Infect Dis. 1(2):87 - 92.

Tuon FF, Kruger M, Terreri M, Penteado-Filho SR, Gortz L. 2011 Klebsiella ESBL bacteremia-mortality and risk factors. Braz J Infect Dis. 15(6):594-598.

Unal S, Garcia-Rodriguez JA. 2005. Activity of meropenem and comparators against Pseudomonas aeruginosa and Acinetobacter spp. isolated in the MYSTIC Program, 2002-2004. Diagn Microbiol Infect Dis. 53(4):265-271.

Widodo D. 2010. Kebijakan penggunaan antibiotika bertujuan meningkatkan kualitas pelayanan pasien dan mencegah resistensi kuman. Cermin Dunia Kedokteran. 37(1): 7-10.

Zarb P, Coignard B, Griskevicienne J, Muller A, Vankerckhoven V, Weist K, Goossens M, Vaerenberg S, Hopkins S, Catry B, Monnet D, Goosens H, Suetens C. 2012. The European Centre for Disease Prevention and Control (ECDC) pilot point prevalence survey of healthcare-associated infections and antimicrobial use. Euro Surveill. 17(46):1 - 16.

Zhanel GG, Wiebe R, Dilay L, Thomson K, Rubinstein E, Hoban DJ, Noreddin AM, Karlowsky JA. 2007. Comparative review of carbapenem. Drugs. 67(7):1027-1052.

Zolldann D, Haefner H, Poetter C, Buzello S, Sohr D, Luetticken R, Lemmen SW. 2003. Assessment of a selective surveillance method for detecting nosocomial infections in patients in the intensive care department. Am J Infect Control. 31(5):261-265. 